\title{
Procedury prawne w zakresie wydatków budżetu państwa (procedury wydatkowe)
}

\section{Legal procedures regarding state budget expenditure}

Streszczenie. Wydatki państwowe oraz prawne procedury ich realizacji można badać na podstawie wielu ustaw, które są podstawą dla wydatków państwa. Procedury dotyczące wydatków budżetu państwa można badać na polu państwowych wydatków osobowych (dotyczących m.in. wynagrodzeń, uposażeń, niektórych emerytur lub świadczeń). Odpowiednie procedury występują w sferze wydatków rzeczowych i inwestycyjnych państwa. Są one określone w regulacjach prawnych dotyczących zamówień publicznych. Obszerną sferą wydatków i związanych $\mathrm{z}$ nimi procedur prawnych stanowią wydatki mające formę dotacji budżetowych (np. celowych, podmiotowych). W celu wykonania ustaleń wydatkowych przewidzianych w ustawie budżetowej potrzebne jest podjęcie przez wykonawców budżetu tysięcy indywidualnych i konkretnych działań lub czynności (np. umów, decyzji i czynności administracyjnych, czynności faktycznych). Dokonywanie wydatków budżetu państwa na rzecz osób trzecich wymaga stosowania procedur polegających na zawieraniu i wykonywaniu umów, podejmowaniu działań związanych z funkcjonowaniem stosunków pracy urzędników i funkcjonariuszy państwowych, stosowaniu decyzji i aktów administracyjnych, wykonywaniu zobowiązań powstających z mocy prawa. Można uznać, że ustalone w ustawie budże- 
towej wydatki mają charakter ustaleń ogólnych, które wymagają dla ich wykonania wielu indywidualnych działań.

Słowa kluczowe: ustawa budżetowa; wydatki państwowe; procedury realizacji wydatków państwowych.

\begin{abstract}
Government spending and the procedures for making them can be examined on the basis of many of public regulations, which are the legal grounds for these expenditure. The procedures of government spending can be studied in the field of personal expenditure of the state budget (including salaries, pensions and social benefits). Appropriate procedures are related to expenditure for purchases of goods and services and for making of public investments (e.g. public roads and buildings). An extensive area of expenditure is in the form of grants. There are special legal ways for transferring the budget grants to different legal organizations and entities. The state expenditure are fixed in the Budget Act. The implementation of the budgetary expenditure needs to take up, by state authorities and agencies, thousands of individual and concrete actions (e.g. the contracts, administrative decisions, other activities). That is, in the Budget Act fixed expenditure have, in principle, normative act features.
\end{abstract}

Keywords: State budget; government spending; procedures in matters of state spending.

\title{
1. Przedmiot i cel opracowania
}

Wydatki ustalone w poszczególnych artykułach i innych przepisach ustawy budżetowej powinny być wykonane. Kto jest wykonawcą tych ustaleń, według jakich zasad i procedur prawnych są realizowane ustalone na dany rok wydatki budżetu państwa, jakie przepisy stanowią o sposobie wydatkowania? Czy można mówić o procedurach dokonywania wydatków? Sądzę, że występują takie procedury. Są one opisane nie tylko w ustawie o finansach publicznych i innych ustawach dotyczących finansów publicznych, ale także w różnych ustawach szczególnych, odnoszących się do różnych dziedzin działalności państwa.

Poszczególne wydatki państwowe oraz procedury ich dokonywania można analizować na podstawie odpowiednich, konkretnych ustaw, które 
są podstawą dla wydatków. W efekcie pojawić się mogą bardzo liczne ustawy (setki ustaw), wynikające $\mathrm{z}$ nich wydatki i procedury ich dokonywania.

Procedury wydatkowe można badać na polu wydatków osobowych budżetu państwa (dotyczących m.in. wynagrodzeń, uposażeń, niektórych emerytur lub świadczeń). Z procedurami tymi związane będą ustawy z zakresu prawa pracy, prawa o urzędnikach i funkcjonariuszach państwowych. Odpowiednie procedury dotyczą wydatków rzeczowych i inwestycyjnych, a stanowią o nich regulacje prawne dotyczące zamówień publicznych. Obszerną sferą wydatków i związanych z nimi procedur stanowią wydatki mające formę dotacji budżetowych (celowych, podmiotowych, przedmiotowych).

Specyficzną kategorią dotacji (form zbliżonych do dotacji) stanowią wydatki na rzecz funduszy ubezpieczeń społecznych, na rzecz poszczególnych państwowych funduszy celowych, na rzecz agencji wykonawczych i instytucji gospodarki budżetowej. Są to wydatki dokonywane wewnątrz sektora finansów publicznych.

Inne znaczenie prawne mają wydatki na obsługę długu publicznego (w tym długu Skarbu Państwa) polegające na wypłatach odsetek i dyskonta od sprzedanych przez Ministra Finansów skarbowych papierów wartościowych, a także wydatki mające formę odsetek od kredytów i pożyczek zaciągniętych przez państwo oraz wypłaty związane z udzielonymi przez Skarb Państwa poręczeniami i gwarancjami. Stosowane w zakresie tych wydatków czynności i procedury mają w zasadzie charakter cywilnoprawny, dotyczą umów Skarbu Państwa $\mathrm{z}$ bankami i innymi podmiotami rynku finansowego.

Według art. 124 ustawy z 27 sierpnia 2009 r. o finansach publicznych $^{1}$ formy wydatków budżetu państwa dzielą się na następujące grupy: dotacje i subwencje, świadczenia na rzecz osób fizycznych (bez wynagrodzeń za pracę), wydatki bieżące jednostek budżetowych (w tym wynagrodzenia i uposażenia oraz zakupy towarów i usług), wydatki majątkowe (w tym wydatki inwestycyjne jednostek budżetowych oraz

1 Dz.U. z 2013 r., poz. 885 ze zm., dalej: u.f.p. 
dotacje na cele inwestycyjne), wydatki na obsługę długu Skarbu Państwa, wydatki na realizację programów finansowanych z udziałem środków europejskich, środki wpłacane przez Polskę do budżetu Unii Europejskiej.

Szczegółowe ujęcie grup i form wydatków ocenić można na podstawie przepisów rozporządzenia Ministra Finansów z dnia 2 marca 2010 r. w sprawie klasyfikacji dochodów i wydatków² ${ }^{2}$ które ustala podział wydatków na kilkaset rozdziałów i paragrafów budżetowych.

W opracowaniu badane będą głównie zagadnienia dotyczące niektórych wydatków osobowych, wydatków mających formę dotacji i wydatków na finansowanie zamówień publicznych. Całościowe ujęcie wszelkich rodzajów wydatków i procedur z nimi związanych wymagałoby opracowania o znacznie większych rozmiarach.

Celem niniejszego opracowania jest rozpoznanie i ustalenie - na podstawie obowiązujących przepisów prawnych - procedur dotyczących dokonywania wydatków. Ustalenia dotyczące procedur wydatkowych rzutować mogą na rozumienie pojęcia - wydatki budżetowe ustalone w ustawie budżetowej. Chodzi o wskazanie, jaki jest charakter prawny zawartych w ustawie budżetowej ustaleń w zakresie wydatków budżetowych, z którymi związane są odpowiednie procedury realizacyjne.

Ustawa budżetowa zawiera także ustalenia po stronie dochodów, a więc pojawia się pytanie o procedury dotyczące poboru, obliczania, wymierzania, przekazywania i rozliczania podatków oraz innych wpływów budżetowych. Po stronie dochodowej występują więc procedury podatkowe, celne, dotyczące opłat i dopłat, wpłat z zysku, dywidend, emisji i sprzedaży obligacji skarbowych, inne. Procedury dotyczące dochodów nie będą jednak przedmiotem tego artykułu.

2 Rozporządzenie Ministra Finansów w sprawie szczegółowej klasyfikacji dochodów, wydatków, przychodów i rozchodów oraz środków pochodzących ze źródeł zagranicznych (Dz.U. z 2014 r., poz. 1053 ze zm.). 


\section{Niektóre wydatki osobowe budżetu państwa i związane z nimi procedury}

Wynagrodzenia i uposażenia, a także inne świadczenia przekazywane z budżetu państwa na rzecz osób fizycznych (np. emerytury niektórych funkcjonariuszy publicznych) należą do grupy wydatków osobowych. Są to wynagrodzenia i uposażenia osób fizycznych pozostających w stosunku pracy, służby lub innym podobnym stosunku prawnym z jednostką organizacyjną państwa (np. z państwową jednostką budżetową) i finansowane z budżetu państwa. Dotyczy to np. wynagrodzeń i uposażeń urzędników państwowych, żołnierzy, policjantów, sędziów, prokuratorów. Konstrukcję, wysokość i składniki wynagrodzeń i uposażeń wspomnianych osób określają odpowiednie ustawy (np. o służbie cywilnej, o Policji, o ustroju sądów powszechnych, o prokuraturze), a także wydawane na ich podstawie rozporządzenia. Wspomniane wynagrodzenia czy uposażenia są elementem wydatków bieżących urzędów i innych państwowych jednostek budżetowych, sądów, jednostek prokuratury, organów władzy państwowej.

Wydatki na wynagrodzenia i uposażenia są efektem regulacji prawnych o uposażeniach i wynagrodzeniach funkcjonariuszy publicznych. Są następstwem wykonywania przez państwo obowiązków wynikających ze stosunku pracy, który wynika z aktów mianowania, powołania, wyboru, umowy o pracę.

W świetle ustawy z dnia 21 listopada 2008 r. o służbie cywilnej ${ }^{3}$ członkami korpusu służby cywilnej są pracownicy zatrudnieni na stanowiskach urzędniczych w urzędach i jednostkach organizacyjnych administracji rządowej, m.in. w Kancelarii Prezesa Rady Ministrów, urzędach ministrów, urzędach centralnych organów administracji rządowej, urzędach wojewódzkich. Członkami korpusu służby cywilnej są pracownicy służby cywilnej, zatrudnieni na podstawie umowy o pracę, i urzędnicy służby cywilnej, zatrudnieni na podstawie mianowania. Według art. 7 ustawy limit mianowań urzędników w służbie cywilnej na dany

3 Dz.U. z 2014 r., poz. 1111 ze zm. 
rok budżetowy i środki finansowe na wynagrodzenia oraz szkolenia członków korpusu służby cywilnej określa ustawa budżetowa. Istotną rolę w realizacji zadań służby cywilnej odgrywają dyrektorzy generalni urzędów (działający m.in. w urzędzie ministra, urzędzie centralnego organu administracji rządowej, urzędzie wojewódzkim). Dyrektor generalny dokonuje czynności z zakresu prawa pracy wobec osób zatrudnionych w urzędzie oraz realizuje politykę personalną, w szczególności przez dokonywanie czynności wynikających z nawiązania i trwania stosunku pracy z członkami korpusu służby cywilnej oraz czynności związanych $\mathrm{z}$ ustaniem stosunku pracy, organizowaniem naboru na wolne stanowiska urzędnicze, dysponowaniem funduszem nagród, administrowaniem środkami zakładowego funduszu świadczeń socjalnych w urzędzie (art. 25 ust. 4 ustawy).

Rozdział 7 (pt. „Uprawnienia członka korpusu służby cywilnej”) stanowi o wynagrodzeniu pracowników i urzędników służby cywilnej, w tym o poszczególnych jego elementach, takich jak: dodatki za wieloletnią pracę, dodatki z tytułu posiadanego stopnia służbowego, dodatki funkcyjne, dodatki zadaniowe, nagrody jubileuszowe, nagrody za szczególne osiągnięcia, jednorazowe odprawy. Wynagrodzenie zasadnicze, dodatek służby cywilnej z tytułu posiadanego stopnia służbowego oraz dodatek funkcyjny ustala się z zastosowaniem mnożników kwoty bazowej, której wysokość określa ustawa budżetowa (art. 87). Niektóre elementy wynagrodzeń dla członka korpusu służby cywilnej (pracownika lub urzędnika) mają charakter fakultatywny, np. dodatek zadaniowy, nagroda z funduszu nagród.

Z ustawy wynikają czynności i procedury związane z ustalaniem wynagrodzeń dla pracowników i urzędników, które związane są z funkcjonowaniem stosunków pracy w służbie cywilnej. Czy są to procedury wydatkowania środków ustalonych w ustawie budżetowej na wynagrodzenia w tej służbie? Wydaje się, że można tak je ocenić. Wynagrodzenia pracowników i urzędników służby cywilnej są bowiem ustalone także jako ustalenia wydatków ustawy budżetowej. Są limitami rocznymi, granicami wydatków. Podstawą dokonywania wydatków dla konkretnego pracownika lub urzędnika z tytułu wynagrodzenia są oczywiście przepisy omawia- 
nej ustawy, wynikające z nich akty mianowania i umowy o pracę, ale także są tu roczne ustalenia wydatków osobowych w służbie cywilnej, wynikające z budżetu. W tych granicach wydatków powinni się zmieścić wykonawcy ustawy budżetowej w zakresie dotyczącym wynagrodzeń w służbie cywilnej, wykonawcy działający głównie poprzez dyrektorów generalnych urzędów. Czynności naboru pracowników, inne czynności dotyczące wynagrodzeń (np. składników wynagrodzeń o charakterze fakultatywnym) są uzależnione od ustalonego w ustawie budżetowej rocznego poziomu wydatków. Przekroczenie wydatków budżetowych (także dotyczących wydatków osobowych) jest jednym z czynów stanowiących naruszenie dyscypliny finansów publicznych, jest więc zagrożone odpowiednimi sankcjami.

Podnieść także trzeba, że ustalenia budżetowe dotyczące poziomu wydatków osobowych w służbie cywilnej mogą być także rozpatrywane pod kątem wymaganej potrzeby dokonania tych wydatków. Nie są one tylko granicą wydatkowania, ale także nakazem, wymogiem, ważnym dla funkcjonowania korpusu urzędników państwa. Wykonawcy ustaleń wydatkowych mogą być więc oceniani także za niewykonanie ustalonych wydatków. Nieosiągnięcie ustalonych wydatków nie jest jednak czynem naruszających dyscyplinę finansów publicznych.

Ustawa z dnia 16 września 1982 r. o pracownikach urzędów państwowych $^{4}$ odnosi się do pracowników państwowych niebędących pracownikami administracji rządowej (np. pracowników Kancelarii Sejmu, Senatu, Prezydenta, pracowników Krajowego Biura Wyborczego) oraz do tych pracowników administracji rządowej, do których nie mają zastosowania przepisy ustawy o służbie cywilnej. Regulacje ustawy o pracownikach urzędów państwowych są zbliżone do uregulowań wskazanych wyżej ustawy o służbie cywilnej. Stanowią one o nawiązaniu, zmianie i rozwiązaniu stosunku pracy, obowiązkach i prawach urzędnika państwowego, nagrodach i wyróżnieniach, odpowiedzialności porządkowej i dyscyplinarnej. Z przepisów tych wynika prawo do odpowiednio obliczanego wynagrodzenia urzędnika, dodatku za wieloletnią pracę, na-

\footnotetext{
$4 \quad$ Dz.U. z 2013 r., poz. 269 ze zm.
} 
grody jubileuszowej, nagrody z zakładowego funduszu nagród, innych świadczeń. Z ustawy tej wynikają wydatki osobowe wspomnianych grup pracowników, ich zakres sposób ustalania i wyliczania, roszczenia urzędników związane z tymi świadczeniami, w tym m.in. procedury dotyczące rozpatrywania sporów o roszczenia urzędników ze stosunku pracy.

Zgodnie z art. 13 ustawy z dnia 6 kwietnia 1990 r. o Policji ${ }^{5}$ koszty związane z funkcjonowaniem Policji są pokrywane z budżetu państwa. Etaty Policji określa coroczna ustawa budżetowa. Przepis ten stanowi także o dotacjach celowych i podmiotowych dla instytutów badawczych wchodzących w skład Policji, a także o środkach finansowych, które mogą przekazywać Policji jednostki samorządu terytorialnego i inne podmioty. Wspomniane środki finansowe przekazywane Policji ujmowane są w państwowym funduszu celowym - Funduszu Wsparcia Policji.

Rozdział 5 ustawy („Służba w Policji) i rozdział 6 („Korpusy i stopnie policyjne”) regulują zagadnienia nawiązywania stosunku służbowego, zmian, zwolnień i innych przekształceń dotyczących stosunków służbowych w Policji oraz struktury stopni i korpusów Policji (np. takich jak korpus oficerów starszych, oficerów młodszych, aspirantów, podoficerów). Według art. 28 ustawy o Policji stosunek służbowy policjanta powstaje $\mathrm{w}$ drodze mianowania na podstawie dobrowolnego zgłoszenia się do służby. Mianowanie może nastąpić: na okres służby przygotowawczej lub kandydackiej, na okres służby kontraktowej i na stałe.

Rozdział 9 ustawy pt. „Uposażenie i inne świadczenia pieniężne policjantów” (art. 99 i n.) wprowadza regulacje dotyczące uposażeń, ich składników, zasad ustalania, wymierzania, zawieszania, ograniczania. Według art. 99 ustawy prawo do uposażenia powstaje $\mathrm{z}$ dniem mianowania policjanta na stanowisko służbowe. Policjant otrzymuje uposażenie i inne świadczenia pieniężne określone w ustawie. Przeciętne uposażenie policjantów (tj. uposażenie wraz z miesięczną równowartością nagrody rocznej) stanowi wielokrotność kwoty bazowej, której wysokość określa ustawa budżetowa. Wielokrotność kwoty bazowej określa Rada

5 Dz.U. z 2015 r., poz. 355 ze zm. 
Ministrów w drodze rozporządzenia. Przykładowo, zgodnie z obecnie obowiązującym rozporządzeniem Rady Ministrów z dnia 26 stycznia 2016 r. ${ }^{6}$ wielokrotność kwoty bazowej, stanowiącą przeciętne uposażenie policjantów, ustalona została na 3,01.

Wysokość uposażenia policjanta jest uzależniona od grupy zaszeregowania jego stanowiska służbowego oraz od wysługi lat. Policjantom przysługuje dodatek za stopień w wysokości uzależnionej od posiadanego stopnia policyjnego, a niektórym policjantom także dodatek funkcyjny, dodatek służbowy, inne dodatki (art. 104). Policjantowi przysługują inne świadczenia pieniężne: zasiłek na zagospodarowanie, nagroda roczna, nagrody motywacyjne, zapomogi, nagrody jubileuszowe, dodatkowe wynagrodzenie za wykonywanie zleconych zadań, należności za podróże służbowe i przeniesienia, świadczenia związane ze zwolnieniem ze służby, inne świadczenia (art. 108 i n.).

System ustalania i obliczania policyjnych uposażeń i dodatków jest rozbudowany. Zawiera m.in. elementy fakultatywne, np. niektóre dodatki, nagrody, zapomogi.

Wprowadzony został także do systemu prawnego niektórych wydatków osobowych ogólny mechanizm kształtowania wynagrodzeń obciążających wydatki budżetu państwa, stosowany w procesie planowania budżetowego, a następnie w procesie wykonywania budżetu. Określony on jest w ustawie o kształtowaniu wynagrodzeń w państwowej sferze budżetowej. Ustawa z dnia 23 grudnia 1999 r. o kształtowaniu wynagrodzeń w państwowej sferze budżetowej ${ }^{7}$ określa niektóre zasady kształtowania wynagrodzeń w tej sferze. Wprowadza ona odpowiednie instytucje dotyczące kształtowania wynagrodzeń: średnioroczny wskaźnik wzrostu wynagrodzeń oraz kwoty bazowe. Kwoty bazowe to prognozowane przeciętne wynagrodzenia w państwowej sferze budżetowej. W ustawie budżetowej ustala się kwoty bazowe, średnioroczne wskaźniki wzrostu wynagrodzeń w państwowej sferze budżetowej, kwoty wynagrodzeń dla państwowych jednostek budżetowych i dla poszczególnych grup pracowników

Dz.U. z 2016 r., poz. 130.

Dz.U. z 2015 r., poz. 2030 ze zm. 
w podziale na części i działy klasyfikacji dochodów i wydatków (art. 9 ustawy o kształtowaniu wynagrodzeń).

Według ustawy pracownicy państwowej sfery budżetowej to osoby objęte mnożnikowymi systemami wynagrodzeń (są to np. osoby zajmujące kierownicze stanowiska państwowe, członkowie korpusu służby cywilnej, prokuratorzy) i osoby nieobjęte mnożnikowymi systemami wynagrodzeń. Średnioroczne wskaźniki wzrostu wynagrodzeń dla osób nieobjętych systemem mnożnikowym są corocznie przedmiotem negocjacji w ramach Rady Dialogu Społecznego.

Zgodnie z ustawą wynagrodzenia powinny być waloryzowane. Kwoty bazowe, służące do obliczania wynagrodzeń w systemach mnożnikowych, są waloryzowane corocznie średniorocznym wskaźnikiem wzrostu wynagrodzeń. Średniorocznym wskaźnikiem wzrostu wynagrodzeń waloryzowane są także wynagrodzenia osób nieobjętych mnożnikowymi systemami (art. 4).

Ustawa o kształtowaniu wynagrodzeń nie odnosi się bezpośrednio do stosunku pracy danego pracownika lub funkcjonariusza, dotyczy planowania i kształtowania systemu wynagrodzeń będących wydatkami budżetu państwa. Pośrednio wpływa ona jednak na indywidualne stosunki prawne dotyczące uposażeń i wynagrodzeń danych osób.

Sądzę, że w ramach wydatków osobowych budżetu państwa na wynagrodzenia i uposażenia dominować będą wydatki stałe, które wynikają z ustawodawstwa. Z wydatkami tymi powiązane są na indywidualne roszczenia względem Skarbu Państwa, które mogą być dochodzone przed sądami pracy lub innymi organami. Aby te wydatki ograniczyć lub inaczej ukształtować, potrzebne są zmiany w odpowiednich ustawach dotyczących wydatków osobowych. W ramach tych wydatków są jednak elementy uznaniowe, fakultatywne i zmienne, wynikające z ustaw dotyczących uposażeń i wynagrodzeń.

\section{Dotacje z budżetu państwa i procedury ich udzielania}

Podstawową formą wydatków budżetowych są dotacje na rzecz wyodrębnionych prawnie, organizacyjnie i finansowo podmiotów. Są to 
dotacje dla jednostek samorządu terytorialnego, organizacji pozarządowych, instytucji kultury, przedsiębiorców, innych podmiotów. Podstawa prawna zastosowania poszczególnych rodzajów dotacji, które ujmowane są w ustawie budżetowej, jest określona w ustawie regulującej daną dziedzinę stosunków społecznych (ustawie szczególnej) ${ }^{8}$.

Dotacje celowe dla stowarzyszeń, fundacji i innych organizacji prowadzących działalność pożytku publicznego są udzielane zgodnie z ustawą o działalności pożytku publicznego na podstawie odpowiedniej umowy zawieranej pomiędzy organizacją pożytku publicznego a organem administracji publicznej. Zgodnie z ustawą z dnia 24 kwietnia 2003 r. o działalności pożytku publicznego i o wolontariacie ${ }^{9}$ działalnością pożytku publicznego jest działalność społecznie użyteczna prowadzona przez organizacje pozarządowe w sferze zadań publicznych (pomocy społecznej, działalności charytatywnej, ochrony i promocji zdrowia, edukacji, wychowania, kultury, kultury fizycznej, bezpieczeństwa publicznego) i wielu innych określonych w art. 4 ustawy.

Organy administracji publicznej wspierają realizację zadań publicznych przez organizacje pozarządowe lub powierzają im realizację tych zadań. Udzielają w związku z tym dotacji celowych na finansowanie lub dofinansowanie realizacji tych zadań (art. 5 ust. 4 ustawy). Stosują odpowiednie procedury (ogłoszenie otwartego konkursu ofert, składanie ofert i ich rozpatrywanie), których efektem jest zawarcie umowy w formie pisemnej (art. 11 i nast. ustawy). Wzory ofert, ramowe wzory umów oraz wzory sprawozdań z wykonania zadania publicznego ustalonego w umowie określa minister właściwy do spraw zabezpieczenia społecznego w drodze rozporządzenia. Organ administracji publicznej zobowiązuje się w ramach wspomnianej umowy do przekazania na realizację zadania odpowiednich środków publicznych w formie dotacji celowej.

8 Por. A. Ostrowska, Charakter prawny i rola dotacji w systemie wydatków publicznych - wybrane zagadnienia [w:] Z. Ofiarski (red.), XXV lat przeobrażeń w prawie finansowym i prawie podatkowym - ocena dokonań i wnioski na przyszłość, Szczecin 2014, s. 115.

$9 \quad$ Dz.U. z 2016 r., poz. 239. 
Ustawa z dnia 24 kwietnia 2003 r. o działalności pożytku publicznego w sprawach dotyczących dotacji celowych uwzględnia regulacje ustawy o finansach publicznych dotyczące tych dotacji. Te dwie ustawy, a także inne przepisy tworzą system określający procedury udzielania dotacji celowych dla organizacji pozarządowych prowadzących działalność w sferze pożytku publicznego, umów w sprawie udzielania tych dotacji, ich wykonywania ${ }^{10}$.

Ustawa o finansach publicznych stanowi także o dotacjach celowych dla organizacji pozarządowych, do których nie mają zastosowania lub nie muszą mieć zastosowania przepisy o działalności pożytku publicznego. Dotyczyć to może dotacji celowych udzielanych organizacjom pozarządowym przez dysponentów części budżetowych. Dysponenci ci (ministrowie, wojewodowie) zawierają z organizacjami pozarządowymi umowy, na podstawie której udzielana jest dotacja celowa (art. 150 i 151 u.f.p.). Z art. 150 u.f.p. wynika, że w przypadku udzielania dotacji celowych - gdy odrębne przepisy nie określają trybu i zasad udzielania dotacji - ma zastosowanie forma umowy.

Odrębną problematyką jest procedura udzielania dotacji celowych dla jednostek samorządu terytorialnego (dalej: j.s.t.). Procedura udzielania dotacji celowych z budżetu państwa dla j.s.t. na zadania zlecone z zakresu administracji rządowej i na zadania własne tych jednostek określona jest głównie w ustawie z dnia 13 listopada 2003 r. o dochodach jednostek samorządu terytorialnego ${ }^{11}$.

Dotacje dla j.s.t. na zadania zlecone i na zadania własne tych jednostek udzielane są według innych zasad prawnych. Dotacje na zadania zlecone mają charakter obowiązkowy, wynikają wprost z ustawy, ich przekazanie j.s.t. jest wykonaniem zobowiązania cywilnoprawnego powstałego z mocy prawa (ex lege). Natomiast dotacje celowe na zadania

10 Por. J.M. Salachna, Granice samodzielności legislacyjnej jednostek samorzq̨du terytorialnego, Gdańsk 2012, s. 257-259.

11 Dz.U. z 2016 r. poz. 198. 
własne mają charakter uznaniowy, udzielane są na podstawie umów lub czynności materialno-technicznych ${ }^{12}$.

W związku z udzielaniem dotacji celowych z budżetu państwa dla j.s.t. ma miejsce przemiana stosunków prawnych: abstrakcyjnych, określonych przez ustawy, na indywidualne, dotyczące danego beneficjenta. Sądzę, że do konkretyzacji i indywidualizacji stosunku dotyczącego dotacji celowej dla j.s.t. dochodzi ${ }^{13}$ :

1. przez czynności ministra lub wojewody, będące wykonaniem zobowiązania wynikającego wprost z ustawy. Czynności te polegają na obliczeniu dotacji na zadanie zlecone i jej przekazania na rachunek j.s.t.,

2. $\quad$ w drodze umów (przewidzianych przez ustawy) z wybranym przez organ dotujący beneficjentem (wybraną j.s.t.), gdy chodzi o dotacje na dofinansowanie niektórych zadań własnych samorządu,

3. w drodze czynności administracyjnych organu dotującego, jeżeli dotacje na dofinansowanie pewnych zadań własnych j.s.t. nie są udzielane na podstawie umowy (nie jest przewidziana forma umowy). Ma tu miejsce obliczenie kwoty i przekazanie dotacji na rachunek.

Z kwestią udzielania dotacji celowych dla j.s.t. powiązane są instytucje (wyraźnie w przepisach nieopisane), które można nazwać „decyzjami budżetowymi”14. Są to konkretne dokumenty (pisma urzędowe) dotyczące wykonania postanowień ustawy budżetowej, wskazujące na kwotę i cel dotacji oraz odpowiednie podziałki klasyfikacji budżetowej, z której ta dotacja wynika. Sądzę, że przekazywana danej j.s.t. dotacja powinna mieć swoją skonkretyzowaną dokumentację urzędową.

Procedura udzielenia dotacji może być sprawą złożoną. Należy ją ustalić głównie $\mathrm{z}$ przepisów (z brzmienia) ustawy szczególnej,

12 Por. A. Borodo, Subwencje i dotacje z budżetu państwa dla jednostek samorzqdu terytorialnego [w:] A. Borodo (red.), Dotacje i subwencje w systemie finansowym samorzqdu terytorialnego, Toruń 2013, s. 29 i n.

13 A. Borodo, Współczesne problemy prawne budżetu państwowego, Toruń 2014, s. 134-135.

14 Por. A. Borodo, Subwencje i dotacje..., s. 36-37. 
wprowadzającej dotacje do danej sfery stosunków społecznych. Przepisy u.f.p w sposób bardzo ogólny mówią o udzielaniu dotacji innych niż dotacje celowe (tj. podmiotowych i przedmiotowych). Odsyłają do odrębnych przepisów.

Jedną z form dotacji budżetowych jest dotacja podmiotowa. Służy ona wyłącznie dofinansowaniu działalności bieżącej podmiotu, w zakresie określonym w odrębnej ustawie (art. 131 u.f.p.). Podmioty uzyskujące dotacje podmiotowe i procedury ich udzielania powinny być określone w odpowiedniej, odrębnej ustawie. Dotacje podmiotowe to w szczególności dotacje dla uczelni publicznych i instytucji kultury. Dotacje podmiotowe są przewidziane w ustawach, określających pozycję, zadania i przychody (w tym dotacje) i inne elementy działalności dotowanych podmiotów.

Przykładowo, art. 12 ustawy z dnia 25 października 1991 r. o organizowaniu i prowadzeniu działalności kulturalnej ${ }^{15}$ stanowi, że organizator instytucji kultury (np. minister) zapewnia instytucji kultury środki niezbędne do rozpoczęcia i prowadzenia działalności kulturalnej oraz do utrzymania obiektu, w którym ta działalność jest prowadzona. Według art. 28 ust. 2 ustawy przychodami instytucji kultury są przychody z prowadzonej działalności, przychody z najmu i dzierżawy składników majątkowych, dotacje podmiotowe i celowe z budżetu państwa lub jednostki samorządu terytorialnego, środki otrzymane od osób fizycznych i prawnych. Organizator przekazuje (art. 28 ust. 3) instytucji kultury środki finansowe $\mathrm{w}$ formie dotacji: 1) podmiotowej na dofinansowanie działalności bieżącej w zakresie realizowanych zadań statutowych, w tym na utrzymanie i remonty obiektów, 2) celowej na finansowanie lub dofinansowanie kosztów realizacji inwestycji, 3) celowej na realizację wskazanych zadań i programów.

Wskazane w tym przepisie dotacje celowe dla instytucji kultury są (w świetle art. 150 u.f.p.) udzielane na podstawie umowy. Natomiast procedura udzielania dotacje podmiotowych nie jest jasno określona, musi być więc przedmiotem odpowiednich zabiegów interpretacyjnych. Dotacje podmiotowe dla instytucji kultury mają charakter obligatoryjny (nie

15 Dz.U z 2012 r. poz. 406 ze zm. 
uznaniowy), wynikają z przedstawionego wyżej przepisu ustawy, ich wysokość (nawiązująca do odpowiednich kalkulacji i wyliczeń) powinna być ustalona w odpowiednim rozdziale i paragrafie ustawy budżetowej lub uchwały budżetowej j.s.t. Dotacja ta przekazywana jest na rachunek instytucji kultury. Ponieważ przekazanie dotacji podmiotowej dla instytucji kultury oparte jest bezpośrednio na regulacji ustawowej (bez umowy dotyczącej tej dotacji) można przyjąć, że jest to wykonanie zobowiązania cywilnoprawnego powstałego z ustawy. Przekazanie wspomnianej dotacji podmiotowej to wykonanie zobowiązania cywilnoprawnego, którego stronami są Skarb Państwa (lub j.s.t.) i dana instytucja kultury (osoba prawna). W tym kontekście wydają się też prawnie dopuszczalne roszczenia instytucji kultury względem organizatora, podnoszone w trybie procesu cywilnego. Przekazując omawianą dotację podmiotową, organizator powinien przesłać pismo urzędowe („decyzję budżetową”) wskazujące na kwotę dotacji i odpowiednie elementy klasyfikacji budżetowej (dział, rozdział, paragrafy) dotyczące przekazywanej dotacji.

Samo przekazanie ocenianej dotacji podmiotowej instytucji kultury jest czynnością faktyczną, która musi jednak wynikać z odpowiedniej podstawy prawnej. Ustawa o organizowaniu i prowadzeniu działalności kulturalnej nie przewiduje - dla konkretnego aktu przekazania dotacji podmiotowej - ani umowy, ani decyzji administracyjnej, ani innej czynności administracyjno-prawnej. Można więc przyjąć, że ustawa ta tworzy bezpośrednio zobowiązanie do przekazania dotacji. Jest to zobowiązanie ustanowione pomiędzy dwiema (formalnie równymi sobie) osobami prawnymi. Wykonaniem tego zobowiązania jest przekazanie dotacji.

Odrębną kategorią dotacji udzielanych i przekazywanych z budżetu państwa są dotacje przedmiotowe. Ich ogólną konstrukcję prawną określa art. 130 u.f.p. Dotacje przedmiotowe to dopłaty do określonych rodzajów wyrobów lub usług, kalkulowane według odpowiednich stawek. Mogą one być udzielane przedsiębiorcom, a także podmiotom wykonujących zadania na rzecz rolnictwa. Kwoty i przedmiot dotacji przedmiotowych ustala także ustawa budżetowa. 
Stawki dotacji przedmiotowych, procedurę ich udzielania i rozliczania, formę składania wniosków, informację o przyjęciu lub odrzuceniu wniosku, warunki przekazywania i rozliczenia dotacji określają rozporządzenia ministra finansów lub innych ministrów.

Wśród dotacji przedmiotowych dla przedsiębiorców występują dotacje do krajowych przewozów pasażerskich, do świadczonych usług pocztowych, do podręczników szkolnych, do posiłków sprzedawanych w barach mlecznych. Podstawą prawną udzielenia dotacji przedmiotowej z budżetu państwa są: przepisy ustawy szczególnej (np. ustawa o publicznym transporcie zbiorowym, Prawo pocztowe, ustawa o pomocy społecznej), ustawa budżetowa, odpowiednie rozporządzenia wykonawcze (występuje kilka rozporządzeń określających stawki dotacji, sposób ich udzielania, rozliczania) ${ }^{16}$.

Z analizy przepisów dotyczących udzielania dotacji przedmiotowych wynika, że choć są one udzielane na wniosek, to jednak nie ma tu umowy o dotację. Udzielenie dotacji przedmiotowej jest dokonywane na podstawie czynności administracyjnej (wywołującej skutki prawne dla beneficjenta i dla organu dotującego). Czynność ta może być oceniona jako rozstrzygnięcie sprawy, jako decyzja administracyjna. Przewidziana w przepisach o dotacjach przedmiotowych informacja w formie pisemnej wydana przez organ państwowy (ministra, dyrektora izby skarbowej) o udzieleniu dotacji lub odmowie jej udzielania ma właśnie cechy prawne decyzji administracyjnej ${ }^{17}$.

\section{Wydatki budżetu państwa na zamówienia publiczne i związane z nimi procedury}

Jednostki sektora publicznego, w tym państwowe jednostki budżetowe, są nabywcami towarów oraz podmiotami realizującymi inwestycje

16 K. Czarnecki, Dotacje przedmiotowe z budżetu państwa dla przedsiębiorców konstrukcja prawna i tryb udzielania [w:] Z. Ofiarski (red.), XXV lat przeobrażeń w prawie finansowym i prawie podatkowym - ocena dokonań i wnioski na przyszłość, Szczecin 2014, s. 47 i n.

17 Tamże, s. 49. 
publiczne. Są stronami umów zawieranych z firmami przemysłowymi, budowlanymi, handlowymi, usługowymi. Są one zamawiającymi w rozumieniu Prawa zamówień publicznych.

Ustawa z dnia 29 stycznia 2004 r. - Prawo zamówień publicznych ${ }^{18}$ wprowadza rozwiązania prawne dotyczące finansowania wydatków nabywczych przez jednostki państwowe (w ramach umowy sprzedaży, dostawy, robót budowlanych) w oparciu o środki publiczne. Reguluje sposób dokonywania wydatków rzeczowych i wydatków inwestycyjnych z budżetu państwa. Zobowiązuje jednostki dysponujące środkami publicznymi do określonego postępowania poprzedzającego zawarcie umowy z przedsiębiorcą, wykonawcą zamówienia. Prawo zamówień publicznych ma umożliwić równe traktowanie wszystkich przedsiębiorców zainteresowanych wykonywaniem zamówień publicznych, uczciwą konkurencję pomiędzy wykonawcami, jawność postępowania, bezstronność i obiektywizm w przeprowadzeniu postępowania.

W Prawie zamówień publicznych zdefiniowane są takie pojęcia, jak: dostawy, roboty budowlane, usługi, zamówienia publiczne, zamawiający, wykonawcy, środki publiczne. Przez dostawy należy rozumieć nabywanie rzeczy, praw oraz innych dóbr w szczególności na podstawie umowy sprzedaży, dostawy, najmu, dzierżawy, leasingu. Zamówienia publiczne są to umowy odpłatne zawierane między zamawiającym a wykonawcą, których przedmiotem są usługi, dostawy lub roboty budowlane.

Ustawę stosuje się do: jednostek sektora finansów publicznych, innych państwowych jednostek organizacyjnych, osób prawnych zależnych od jednostek sektora publicznego, podmiotów wykonujących działalność w sferze tzw. zamówień sektorowych (np. poszukiwanie i wydobywanie gazu ziemnego, ropy naftowej, zarządzanie lotniskami i portami, tworzenie sieci dotyczących energii elektrycznej), podmiotów, w przypadku których ponad 50\% wartości udzielanego przez nie zamówienia jest finansowana ze środków publicznych, innych (art. 3 ustawy).

18 Dz.U. z 2015 r., poz. 2164. 
Według Prawa zamówień publicznych podstawowymi trybami udzielania zamówienia publicznego są przetarg nieograniczony oraz przetarg ograniczony. W przypadkach przewidzianych w ustawie zamawiający może ponadto udzielić zamówienia $\mathrm{w}$ trybie negocjacji $\mathrm{z}$ ogłoszeniem, dialogu konkurencyjnego, negocjacji bez ogłoszenia, zamówienia z wolnej ręki, zapytania o cenę i licytacji elektronicznej (art. 10).

Za przygotowanie i przeprowadzenie postępowania o udzielenie zamówienia odpowiada kierownik jednostki sektora finansów publicznych. W przypadku zamówień publicznych, których wartość przekracza określoną kwotę, powinna być powołana komisja przetargowa. Przepisy o zamówieniach publicznych zobowiązują do przedstawiania ogłoszeń związanych z procedurą zamówienia. Ogłoszenia publikowane są w Biuletynie Zamówień Publicznych oraz w Dzienniku Urzędowym Unii Europejskiej.

Elementem procedury o udzielenie zamówienia publicznego jest specyfikacja istotnych warunków zamówienia, którą przygotowuje i przedstawia zamawiający. Specyfikacja ta zawiera m.in.: tryb udzielenia zamówienia, opis przedmiotu zamówienia, termin wykonania, informację o oświadczeniach i dokumentach, jakie mają dostarczyć wykonawcy, wymagania dotyczące wadium, termin związania ofertą, opis sposobu przygotowania ofert, opis kryteriów, którymi zamawiający będzie się kierował przy wyborze oferty, opis sposobu obliczenia ceny (art. 36).

Efektem postępowania prowadzonego w trybie określonym przez ustawę jest zawarcie umowy w sprawie zamówienia publicznego. Do umów tych stosuje się przepisy kodeksu cywilnego, o ile przepisy Prawa zamówień publicznych nie wprowadzają własnych rozwiązań (art. 139).

W sferze zamówień publicznych występują regulacje dotyczące środków ochrony prawnej, którymi są: odwołanie i skarga. Środki te mogą wnosić wykonawcy, uczestnicy konkursu, inne osoby, a także organizacje zrzeszające wykonawców. Odwołanie wnosi się do Prezesa Krajowej Izby Odwoławczej, a rozpatruje je skład orzekający tej Izby. O oddaleniu odwołania lub jego uwzględnieniu Izba orzeka w wyroku. Na orzeczenie Izby stronom przysługuje zaś skarga do sądu, którą wnosi się do sądu 
okręgowego właściwego dla siedziby albo miejsca zamieszkania zamawiającego.

Wydatki na rzecz finansowania zamówień publicznych są związane z wykonywaniem umowy cywilnoprawnej, są efektem zawarcia i wykonania umowy, jaką jest zamówienie publiczne. Umowa ta zawiera w sobie elementy publicznoprawne (administracyjnoprawne). Ma charakter hybrydowy, łączy elementy publiczne i prywatnoprawne ${ }^{19}$.

Do niektórych umów zawieranych przez jednostki sektora publicznego nie stosuje się Prawa zamówień publicznych. Wykaz umów, do których nie stosuje się tego prawa, zawiera głównie art. 4 ustawy. W szczególności procedury Prawa zamówień publicznych nie dotyczą zamówień o wartości nieprzekraczającej 30000 euro (art. 4 pkt 8). Poniżej tej kwoty umowy dotyczące zakupów są więc zawierane tylko według procedur prawa cywilnego. Przy ich zawieraniu obowiązują jednak limity (granice) wydatków określone w rozdziałach i paragrafach ustawy budżetowej na dany rok.

\section{Procedury wydatków budżetowych a procedura wykonywania ustawy budżetowej}

Wykonywanie budżetu państwa jest to wykonywanie zarówno samej ustawy budżetowej, jak i wielu innych regulacji, np. prawa o dotacjach budżetowych, o zamówieniach publicznych, o wydatkach osobowych, o rachunkowości, oczywiście - ustawy o finansach publicznych (zwłaszcza art. 146 i nast. u.f.p.). Jednakże całość prawodawstwa jest uwzględniana w procesie wykonywania ustawy budżetowej. Wykonywanie ustawy budżetowej to wykonywanie zadań wynikających z wielu ustaw, które są ze sobą powiązane. Przy wykonywaniu budżetu państwa chodzi przecież nie tylko o ustalenia budżetowe, lecz także o regulacje odnoszące się do różnych zadań publicznych, kompetencji organów, prawnych form działalności podmiotów państwowych, wielu procedur prawnych.

19 Por. W. Miemiec, Zagadnienia finansowoprawne zamówień publicznych $w$ działalności jednostek samorzqdu terytorialnego, Wrocław 2013. 
Ustawa budżetowa jest upoważnieniem dla organów administracji rządowej i innych organów państwa do dokonywania wydatków, które udzielone jest przez ustawodawcę na dany rok. Jednak upoważnienie to nie jest „puste”, blankietowe. Może być wykonywane tylko w ramach i przy pomocy instrumentarium prawnego zawartego w całym ustawodawstwie.

Wykonawcami budżetu państwa są: Rada Ministrów, Minister Finansów, ministrowie, kierownicy urzędów centralnych, wojewodowie, państwowe jednostki organizacyjne, których dochody i wydatki ustalone są w ustawie budżetowej. Głównymi wykonawcami budżetu państwa są państwowe jednostki budżetowe (urzędy państwowe, jednostki policji, instytucje wojskowe), sądy, inne organy państwa. Są one dysponentami środków budżetowych (I, II lub III stopnia).

Dokonywanie wydatków następuje w granicach kwot określonych w planie finansowym danej jednostki państwowej (wynikającym bezpośrednio z ustawy budżetowej), z uwzględnieniem przeniesień wydatków (art. 162 pkt 3 u.f.p.). Wydatki budżetowe mogą być przenoszone (pomiędzy rozdziałami i paragrafami) przez dysponentów środków budżetowych zgodnie zasadami określonymi w art. 171 u.f.p. (np. według art. 171 ust. 7 u.f.p. przeniesienia wydatków nie mogą zwiększać planowanych wydatków na uposażenia i wynagrodzenia ze stosunku pracy).

Regułą dotyczącą wykonywania budżetu i odzwierciedlającą mechanizm funkcjonowania budżetu jest zasada, że niezrealizowane kwoty wydatków budżetowych wygasają z upływem roku budżetowego (art. 181 ust.1 u.f.p.). Wygasanie niezrealizowanych kwot wydatków oznacza wygaśnięcie uprawnień kierownika danej jednostki do dokonania wydatku w związku z upływem roku budżetowego.

Przeniesienia wydatków, blokownie wydatków, możliwość stosowania rozwiązań co do niewygasania niektórych wydatków powodują, że ma miejsce przesuwanie uprawnień do dokonywania wydatków w stosunku do uprawnień przyznanych w pierwotnym brzmieniu ustawy budżetowej. W ramach wykonywania budżetu działania wykonawców budżetu w niektórych przypadkach są operacjami dotyczącymi przesuwania upoważnień do wydatkowania (przenoszenie, wygasanie, blokowanie), w innych przy- 
padkach chodzi o operacje polegające na przekazywaniu środków na rachunek bankowy dysponenta przez dysponenta wyższego stopnia, co umożliwia dokonywanie wydatków przez dysponenta niższego stopnia. Ta ostatnia operacja jest m.in. działaniem dotyczącym zasilania i funkcjonowania rachunków bankowych budżetu państwa. Muszą być także stosowane działania ewidencyjne i rachunkowe dotyczące zapisywania dokonanych wydatków na odpowiednich kontach księgowych budżetu państwa i poszczególnych dysponentów ${ }^{20}$.

Realizacja wydatków budżetowych - z reguły w końcowej fazie dokonywania wydatków - realizowana jest przez płatność, zapłatę za usługę, dostawę lub za pracę, za inne świadczenie, dokonywane jest przekazanie dotacji. Łączy się z tym sprawa dysponowania środkami budżetowymi przez uprawnionego dysponenta. Dyspozycja środkami budżetowymi jest oddzielona od jej kasowego wykonania. Osoba uprawniona do podejmowania decyzji w sprawie wydatkowania środków budżetowych nie jest uprawniona do wykonywania dyspozycji środkami budżetowymi, znajdującymi się na rachunku bankowym jednostki ${ }^{21}$.

Za całość gospodarki finansowej jednostki sektora finansów publicznych jest odpowiedzialny kierownik tej jednostki (art. 53 u.f.p.). Kierownik może powierzyć określone obowiązki w zakresie gospodarki finansowej pracownikom tej jednostki, w szczególności głównemu księgowemu, tj. pracownikowi, któremu kierownik jednostki powierza obowiązki i odpowiedzialność w zakresie: prowadzenia rachunkowości jednostki, wykonywania dyspozycji środkami pieniężnymi, dokonywania wstępnej kontroli zgodności operacji gospodarczych i finansowych z planem finansowym, dokonywania wstępnej kontroli kompletności i rzetelności dokumentów dotyczących operacji gospodarczych i finan-

20 Por. rozporządzenie Ministra Finansów z dnia 5 lipca 2010 r. w sprawie szczególnych zasad rachunkowości oraz planów kont dla budżetu państwa, budżetów jednostek samorządu terytorialnego, jednostek budżetowych, samorządowych zakładów budżetowych, państwowych funduszy celowych oraz państwowych jednostek budżetowych mających siedzibę poza granicami Rzeczypospolitej Polskiej (Dz.U. z 2013 r., poz. 289 ze zm.).

21 E. Malinowska-Misiąg, W. Misiąg, Finanse publiczne w Polsce, Warszawa-Rzeszów 2006, s. 528. 
sowych (art. 54 u.f.p.). Dowodem dokonania przez głównego księgowego jednostki sektora finansów publicznych wstępnej kontroli operacji gospodarczych i finansowych jest jego podpis złożony na dokumentach dotyczących tej operacji.

Wykonywanie ustawy budżetowej uregulowane w ustawie o finansach publicznych to głównie procedury dotyczące wewnętrznych, zachodzących w ramach struktury państwa, aspektów wydatkowania, m.in. dotyczących dysponentów budżetowych, przekazywania środków w ramach systemu dysponentów, wygasania i przenoszenia wydatków, rachunków bankowych budżetu i ich funkcjonowania, zagadnień rachunkowości budżetowej. Są to procedury dokonywane w ramach aparatu państwowego, realizującego ustawę budżetową. Jednak ta „wewnętrzność” wskazanych tu procedur może być częściowo kwestionowana. Poszczególne organy państwa (np. ministrowie) mają bowiem swoją odrębność prawną, kompetencyjną i budżetową.

\section{Podsumowanie}

Ustalenia ustawy budżetowej, które występują po stronie wydatków, mają znaczenie prawne dla czynności podejmowanych przez wykonawców budżetu. Oczywiście podstawy prawne dla wydatków są przewidziane w ustawach szczególnych, jednak ustawa budżetowa ustala granice wydatków, które obowiązują wykonawców.

Dla wykonania ustaleń wydatkowych zawartych w ustawie budżetowej potrzebne jest podjęcie (przez wykonawców budżetu) tysięcy indywidualnych i konkretnych działań lub czynności (np. umów, decyzji i czynności administracyjnych, czynności faktycznych). W tym kontekście ustalenia wydatków wykazują cechy ogólności, dla ich wykonania konieczne jest zastosowanie różnych czynności indywidualnych.

Ustaleniami wydatków ustawy budżetowej są m.in. ustalenia dotyczące wynagrodzeń i uposażeń pracowników. Ustalenia te są limitami rocznymi. Podstawą dokonywania wydatków dla konkretnego pracownika lub urzędnika z tytułu wynagrodzenia są przepisy odpowiedniej ustawy 
(np. o służbie cywilnej, o Policji), ale także powinny być uwzględniane roczne ustalenia wydatków osobowych wynikające $\mathrm{z}$ budżetu. Zatrudnianie urzędników i funkcjonariuszy, różne czynności dotyczące wynagrodzeń (np. odnoszące się do składników wynagrodzeń o charakterze fakultatywnym lub uznaniowym) są zależne od ustalonego w ustawie budżetowej rocznego poziomu wydatków, a także ustaleń tej ustawy dotyczących kwoty bazowej i wskaźnika wzrostu wynagrodzeń. Przekroczenie wydatków budżetowych (także osobowych) jest jednym z czynów stanowiących naruszenie dyscypliny finansów publicznych.

Forma prawna udzielania dotacji z budżetu państwa jest różna dla poszczególnych rodzajów dotacji. Dla udzielenia dotacji stosowana jest forma umowy, forma czynności administracyjnej lub decyzji administracyjnej, albo też przekazanie dotacji (np. dla samorządu lub instytucji kultury) jest wykonaniem powstałego $\mathrm{z}$ mocy ustawy zobowiązania. Gdy zastosowana jest forma umowy cywilnoprawnej, to nie oznacza, że stosunki dotacyjno-prawne stają się w pełni stosunkami prawa cywilnego. Umowy organów dotujących z beneficjentami dotacji są prawnymi formami działania administracji, stanowią formę realizacji kompetencji organu państwa w zakresie udzielenia dotacji.

Rozbudowaną grupę procedur wydatkowania środków publicznych wprowadzają przepisy o zamówieniach publicznych. Według Prawa zamówień publicznych trybami udzielania zamówienia publicznego są: przetarg nieograniczony, przetarg ograniczony, negocjacje z ogłoszeniem, dialog konkurencyjny, negocjacje bez ogłoszenia, zamówienie z wolnej ręki, zapytanie o cenę, licytacja elektroniczna. Do zamówień publicznych stosuje się przepisy kodeksu cywilnego, o ile przepisy Prawa zamówień publicznych nie stanowią inaczej. Przy zawieraniu i wykonywaniu umów w sprawie zamówień publicznych oraz innych umów dotyczących nabywania towarów i usług obowiązują limity wydatków, określone w rozdziałach i paragrafach ustawy budżetowej na dany rok.

Procedury wykonywania ustawy budżetowej określone w ustawie o finansach publicznych są to na ogół procedury wewnętrzne (występujące w ramach aparatu państwowego), m.in. dotyczące rachunków bankowych, ich dysponentów (decydujących o wydatkach i wykonujących dyspozycje 
wydatkowe), związane z przekazywaniem środków w ramach systemu dysponentów oraz przenoszeniem i wygasaniem wydatków. Jednak dokonywanie wydatków budżetu państwa na rzecz osób spoza budżetu państwa, na rzecz osób trzecich, nakazuje stosować procedury „zewnętrzne” polegające na zawieraniu i wykonywaniu umów, w tym umów w sprawie zamówień publicznych, podejmowaniu różnych działań w ramach stosunków pracy, stosowaniu decyzji administracyjnych i czynności administracyjnych, wykonywaniu zobowiązań powstających ex lege, stosowaniu innych procedur.

\section{Bibliografia:}

Borodo A., Subwencje i dotacje z budżetu państwa dla jednostek samorzqdu terytorialnego [w:] A. Borodo (red.), Dotacje i subwencje w systemie finansowym samorzqdu terytorialnego, TNOiK, Toruń 2013.

Borodo A., Współczesne problemy prawne budżetu państwowego, Wydawnictwo Naukowe Uniwersytetu Mikołaja Kopernika, Toruń 2014.

Czarnecki K., Dotacje przedmiotowe z budżetu państwa dla przedsiębiorców konstrukcja prawna i tryb udzielania [w:] Z. Ofiarski (red.), XXV lat przeobrażeń w prawie finansowym i prawie podatkowym - ocena dokonań wnioski na przyszłość, Wydawnictwo Uniwersytetu Szczecińskiego, Wydział Prawa i Administracji, Szczecin 2014.

Malinowska-Misiąg E., W. Misiąg, Finanse publiczne w Polsce, Lexis Nexis, Warszawa-Rzeszów 2006.

Miemiec W., Zagadnienia finansowoprawne zamówień publicznych $w$ działalności jednostek samorzqdu terytorialnego, Prawnicza i Ekonomiczna Biblioteka Cyfrowa, Wrocław 2013.

Ostrowska A., Charakter prawny i rola dotacji w systemie wydatków publicznych - wybrane zagadnienia [w:] Z. Ofiarski (red.), XXV lat przeobrażeń w prawie finansowym i prawie podatkowym - ocena dokonań i wnioski na przyszłość, Wydawnictwo Uniwersytetu Szczecińskiego, Wydział Prawa i Administracji, Szczecin 2014.

Salachna J.M., Granice samodzielności legislacyjnej jednostek samorzq̨u terytorialnego, ODDK, Gdańsk 2012. 